\title{
Ancient Biographies of Pythagoras and Epicurus as Models of the Philosophical Life
}

Dominic J. O'Meara

\section{(2) OpenEdition}

12 Journals

Electronic version

URL: https://journals.openedition.org/philosant/3192

DOI: $10.4000 /$ philosant.3192

ISSN: 2648-2789

\section{Publisher}

Éditions Vrin

\section{Printed version}

Date of publication: 31 October 2019

Number of pages: 151-165

ISBN: 978-2-7574-2534-3

ISSN: 1634-4561

\section{Electronic reference}

Dominic J. O'Meara, "Ancient Biographies of Pythagoras and Epicurus as Models of the Philosophical Life", Philosophie antique [Online], 19 | 2019, Online since 31 October 2020, connection on 02 December 2022. URL: http://journals.openedition.org/philosant/3192 ; DOI: https://doi.org/10.4000/philosant. 3192

\section{(c) (†) $\odot$}

Creative Commons - Attribution-NonCommercial-NoDerivatives 4.0 International - CC BY-NC-ND 4.0 https://creativecommons.org/licenses/by-nc-nd/4.0/ 


\title{
ANCIENT BIOGRAPHIES OF PYTHAGORAS AND EPICURUS AS MODELS OF THE PHILOSOPHICAL LIFE
}

\author{
Dominic J. O’MEARA
}

Université de Fribourg

RÉSUMÉ. Cet article a pour objet le rapport éventuel entre la biographie épicurienne, dans sa fonction de proposer des modèles de félicité humaine, et la biographie telle qu'elle est pratiquée dans le platonisme de l'Antiquité tardive, notamment dans le $D e$ vita Pythagorica de Jamblique. Il est montré que des traits du portrait de Pythagore, tel que Jamblique le représente, le mode de vie qu'il cultivait et qu' il enseignait à ses disciples, évoquent des éléments spécifiques à l'éthique d'Épicure. La manière dont la biographie avait été pratiquée dans les écoles épicuriennes, servant à proposer des exemples de la vie du sage, à imiter et assimiler par les membres de l'école, fait l'objet d'une deuxième section. Enfin, plus généralement, il est noté que l'éthique épicurienne a pu trouver place dans la philosophie néoplatonicienne, chez Porphyre et chez Jamblique, au niveau de la vie pratique, de la discipline du corps et des désirs corporels.

SUMmARY. In this paper I explore possible connections between Epicurean biography, in its function as providing models of human felicity, and late antique Platonist biography, in particular Iamblichus' De vita Pythagorica. I first note that Iamblichus' portrait of Pythagoras' life-style, as he lived it and taught it to his disciples, includes a number of traits to be found specifically in Epicurean ethics. I then bring out the function biography played in Epicurean schools in exemplifying a life of the sage to be imitated and inculcated by members of the school. Finally, I point to the integration of Epicurean ethical ideas more generally in Neoplatonic philosophy, in Porphyry as well as in Iamblichus, ideas seen as pertinent to practical ethics, to the discipline of the body and of bodily desires.

Philosophie antique, n¹9 (2019), 151-165 

The philosophical literature of late antique Platonism includes a number of portraits of philosophers depicted as ideal sages, as quasi-divine sources of knowledge, pure souls sent down by the gods to save humanity from ignorance, confusion, moral degradation and perdition, our guides for the return to a higher life in a transcendent existence. Such are the figures of Plotinus in Porphyry's Vita Plotini, of Pythagoras in Iamblichus' De vita Pythagorica, of Proclus in Marinus' Vita Procli and of Plato at the beginning of Olympiodorus' commentary on Plato's Alcibiades." We might speak of these 'lives' of the philosophers (and there are others) as a sort of pagan hagiography, lives of philosophical 'holy men' which, in late Antiquity, the reader could find at the beginning of an edition or curriculum of works (Porphyry's edition of Plotinus, Iamblichus' Pythagorean curriculum, Olympiodorus' lectures on Plato) or encounter as a commemorative speech (Marinus). ${ }^{1}$

To speak of such biographies as 'hagiography' is to suggest a comparison with the literature of Christian hagiography which developed over the same period. This comparison will lead, in turn, to questions about the relations between pagan and Christian hagiography: might there be, for example, a relation between Iamblichus' De vita Pythagorica and Athanasius' Vita Antonii? In this paper, however, I propose pursuing a different line of investigation, one concerning the philosophical precedents to late antique Platonist biography. In particular I would like to go back to the idealized, heroized image of Epicurus, as this image functioned as an inspirational model in the Epicurean schools. Epicurus was seen, in these schools, as a quasi-divine saviour of humanity who brought a knowledge which could dispel the false

* Earlier versions of this paper were presented as the 2014 Shlomo Pines Memorial Lecture (Israel Academy of Sciences and Humanities, Jerusalem), at the Université de Lille 3, at the Pavol Jozef Šafárik University (Košice) and at the University of Durham. I am very grateful for the questions and suggestions I received on these occasions and for the comments made by the two readers for Philosophie antique, which helped to clarify the argument of the paper.

1. A good deal of work has been published more recently on these biographies. See for example Goulet 2001; Urbano 2013; Bonazzi \& Schorn 2016; Hartmann 2018. 
opinions humans have (about the gods and about death) and the vain desires which make them suffer. The lives of Epicurus and of his closest disciples were recounted regularly in the Epicurean schools as providing models of the happiness that the practice of Epicurus' philosophy could bring. I would like here to explore this edificatory use of the biography of Epicurus in the Epicurean schools, to the extent that it might have been a precedent, in part, for the analogous use made of biographies by late antique Platonists.

Referring to Epicurus in this connection may seem strange. Much separates Epicureanism from late antique Platonism: they are directly opposed to each other on fundamental questions such as the role of the gods in the workings of the universe and in human life, the survival of the soul after death, the value of sense-perception, the nature of happiness. ${ }^{2}$ However, the comparison I wish to make concerns not only doctrines, but also the pedagogic, or rather 'psychagogic' function given to figures of sages as saviours who can inspire and lead humans to a divine life. I propose comparing in particular the figure of Pythagoras in Iamblichus' De vita Pythagorica with that of Epicurus as idealized in the Epicurean tradition. ${ }^{3}$ I begin (I) with the portrayal of Pythagoras in Iamblichus' text, noting Epicurean traits in the image he gives of Pythagoras. Then I take up (II) the function Epicurus had as a model in the Epicurean schools, before returning (III) to a more general comparison between the figures of Epicurus and of Pythagoras, to the question of Iamblichus' sources and to the wider presence of Epicurean ethical ideas in late antique Platonism.

\section{I}

At the beginning of his De vita Pythagorica, Iamblichus presents Pythagoras as a superior, divine-like soul, a companion of Apollo, which has been sent down to us in this world $(7,27-8,2)$. He is the bearer of a saving knowledge for humans, as a later passage describes him:

They [the people of Croton] counted him among the gods [...] Some called him Apollo [...] some said one, some another, of the Olympians, who had appeared in human form to the people of that time for the benefit and amendment of mortal life, and to grant mortal nature the saving spark of happiness and philosophy. No greater good has ever come, or ever will come, as a gift of the gods. ${ }^{4}$

2. See, for example, O’Meara 1999, p. 83 and 2000, p. 243-251.

3. More generally on Pythagoras as a model figure in ancient literature see Macris 2006.

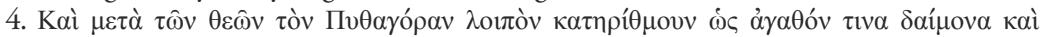

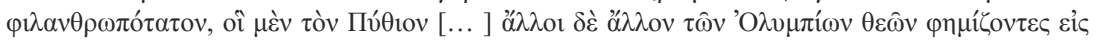

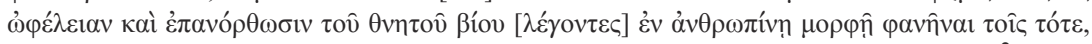

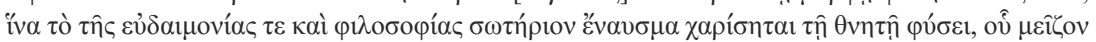

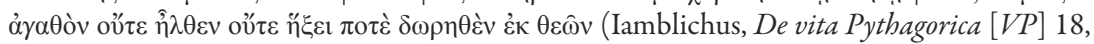


The knowledge brought by Pythagoras, according to Iamblichus' account, consisted in a range of sciences including mathematics, music, medicine, political science, theology, in short all that is required for humans to improve and correct their lives and reach happiness. ${ }^{5}$

Already, as a young man in Samos, Pythagoras appeared to be divine and was much admired. His mode of life was exemplary:

He regulated his life by worship, study and a well-chosen regime: his soul was in balance (eustatheia) and his body controlled, his speech and action showed an inimitable serenity (galene) and calm; no anger, mockery, envy, aggression or any other perturbation (tarache) or rash impulse, took hold of him. ${ }^{6}$

The words Iamblichus uses in describing Pythagoras' stable 'balance' of soul and body, his serenity, are reminiscent of Epicurean terminology. ${ }^{7}$ Pythagoras' freedom from all 'perturbation' also evokes the Epicurean ideal of ataraxia, a freedom from perturbation which reappears later in the $D e$ vita Pythagorica. ${ }^{8}$ Ataraxia was of course an ambition shared in common by Hellenistic philosophers, but here, in Iamblichus, it appears in conjunction with Epicurean terminology.

Later, in Italy, as a teacher, Pythagoras taught this same tranquillity of soul and body to his followers. On his instructions,

They took a morning walk, alone, in places where peace and quiet (hesuchia) were appropriate, where there were shrines or sacred groves or other delights of the heart. They thought it wrong to meet people before one's own soul is stable and one's mind adjusted, and this tranquillity (hesuchia), they thought, helped to settle (katastasis) the mind, whereas it is disturbing to get up and immediately push one's way through crowds. ${ }^{9}$

3-10). I cite the text by page and line number in Deubner's edition (Deubner 1975) and in the translation by Clark 1989. The last line of this passage comes from Plato's Timaeus 47b1-2.

5. VP 88, 24-92, 22 ; 97, 5-6 with 3, 24-27.

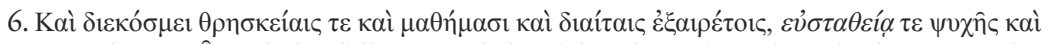

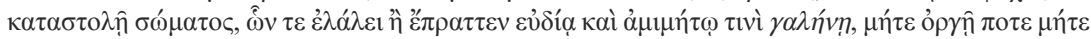

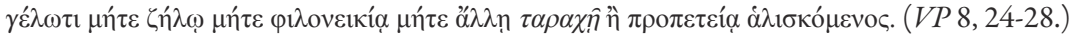

7. Compare the passage in Iamblichus with Epicurus: 'For the balanced state (eustathes... katastema) of the body and the reliable hope about it holds the highest and most stable joy for those who can reflect' (a quote from Epicurus in Plutarch, Non posse suaviter vivi 1089D

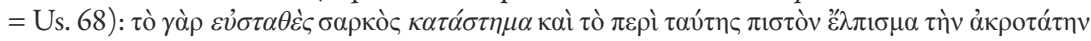

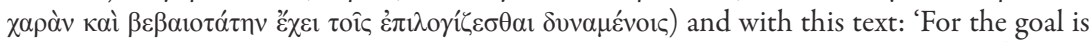
to be of good spirit [... ] according to which the soul lives serenely and in balance (galenos kai eustathos).' (Diogenes Laertius, Lives of the Philosophers, IX, 45 = Usener, Glossarium

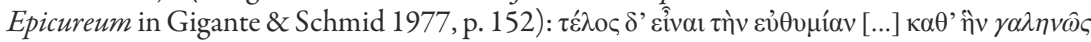

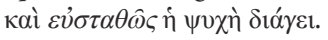

8. VP 12, 25; 107, 25; 112, 28. For Epicurean ataraxia, see Epicurus' Letter to Herodotus (82), Letter to Pythocles $(85,96)$ and Letter to Menoeceus $(128)$.

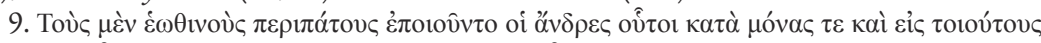

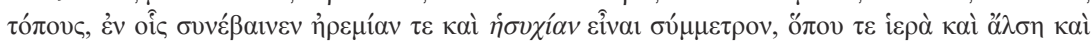


In the evening, music was used to restore this tranquillity:

When they went to bed they used particular songs and special tunes to clear their minds of the day's troubles (tarachon) and preoccupations, and to make their sleep calm and visited by few dreams, and those pleasant ones. ${ }^{10}$

Towards the end of his book, Iamblichus sums up this Pythagorean practice of serenity in body and soul as follows:

They try to keep their bodies in the same condition, not skinny at one time and fleshy at another, for that, they thought, was the proof of an irregular life (anomalou...biou). Similarly, in mind, they aimed at a moderate and consistent (eph' homalou) happiness, not full of gladness at one time and downcast at another. They fended off anger, depression and perturbation (tarachas). ${ }^{11}$

We can see from this that for Pythagoras, tranquillity of body was to be achieved by following an appropriate, balanced diet. ${ }^{12}$ The soul could be kept serene, untroubled, by excluding passions. In connection with the latter, Iamblichus mentions a distinction between desires which are natural (phusikai) and the many desires which humans add (epiktetai) and devise. ${ }^{13}$ The distinction reminds us of the Epicurean distinction between natural and unnecessary desires, and, as in Epicureanism, ${ }^{14}$ the Pythagoreans remain untroubled (ataraktoi) by means of a correct training of desires. In describing how desires can be limited to what is necessary, or can be unnecessary,

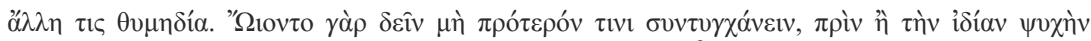

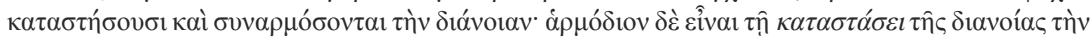

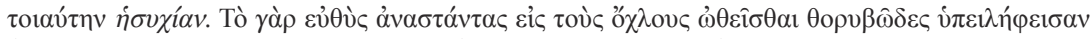
(VP 56, 4-14). In Porphyry's version (VP 32) of this story (both Porphyry and Iamblichus are using a lost work of Nicomachus as their source), it is Pythagoras who goes, with a few others, for a morning walk and there is no mention of a katastasis. For Epicurean hesuchia, see Epicurus, Principal Doctrines, 14.

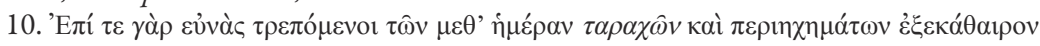

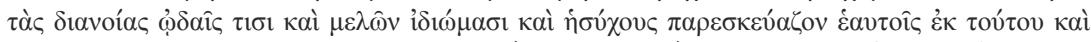

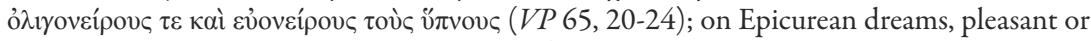
troubling, see Diogenes of Oinoanda fr. 43.II (Smith 1993).

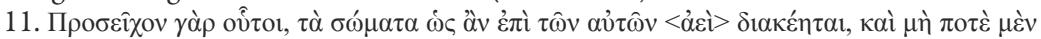

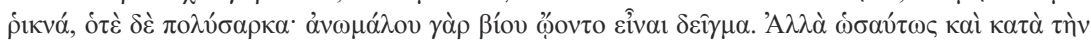

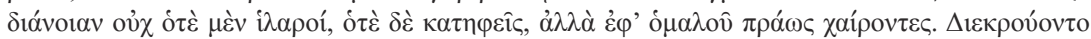

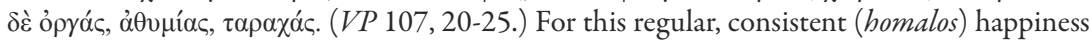
compare 'To try to make the later greater than the former, so long as we are on the way; but once we reach the limit, to be of consistent good cheer (homalos euphrainesthai)' (Epicurus,

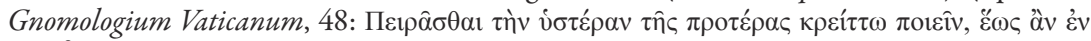

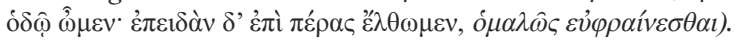

12. On this diet see $V P$ 56, 24-26 and 57, 11-15.

13. VP 112, 3-113, 5 .

14. The comparison of this passage in Iamblichus with the Epicurean division of desires has been made by Staab 2002, p. 404 n. 994; on the division of desires see Epicurus' Letter to Menoeceus, 127 and Principal Doctrines, 29-30. 
infinite and the source of great perturbation, Iamblichus' Pythagoreans echo the Epicurean arguments which Porphyry had incorporated in his treatise in favour of vegetarianism. ${ }^{15}$ Indeed the passages in Iamblichus and Porphyry are sometimes so close that one may wonder if both philosophers are using the same (Epicurean) source. ${ }^{16}$ However, Iamblichus' Pythagorean is not a strict vegetarian. And, in contrast to Epicurus, he considers pleasure to be a passion to be avoided: it is not the goal of life (VP 111, 22-29).

The untroubled life also means eliminating disagreements and conflicts in domestic and social relations. In referring to disagreement, Iamblichus uses (VP 20,5-6) a word, heterophrosune, which appears to be a hapax, a precedent being found in an Epicurean saying. ${ }^{17}$ The Epicureans were famous for the unanimity (homonoia) which reigned in their school. Numenius of Apamea, a second-century Pythagorizing Platonist, referred with envy to this like-mindedness of the Epicureans: they achieved what Plato, in his ideal republic, had imagined, but which the Platonists themselves betrayed in their unceasing quarrels. ${ }^{18}$ Iamblichus' Pythagoreans enjoyed this unanimity (VP 17, 21), also sharing everything in common $(17,23)$, another feature of the life of philosophers in Plato's ideal state. It appears, however, that the Epicureans did not go this far: it is reported of them ${ }^{19}$ that they did not hold to sharing everything in common.

Finally, to this list of Epicurean traits in Iamblichus' portrayal of Pythagoras, of the way in which he lived and the life-style which he taught to his disciples, one might add the emphasis Iamblichus gives to the way in which Pythagoras' followers learned his teaching by memorizing maxims, sentences (parangelmata, akousmata), received as if they were divine truths (theia dogmata, VP 47,7). Of course, these maxims, in a number of cases, are genuinely Pythagorean and go back to the early days of the movement. But their integration in a concept of philosophical pedagogy which evokes Epicurean ideas is all the more interesting in that maxims also had a systematic place in Epicurean pedagogy. Let us go back then to Epicurus' school and to the inspirational role which his biography played for his followers.

15. Iamblichus, VP 112, 3-113, 28; Porphyry, Abst. I, 49-55. Porphyry refers to the Epicureans at 48, 3 and to Epicurus at 49, 1 (phesin). On the Epicurean sources in Porphyry's text see Bouffartigue \& Patillon 1977, p. 15-25.

16. Compare for example Iamblichus, VP 113, 7-17 with Porphyry, Abst. I, 51, 5-6; 53, 1 and 55, 3. For a critique of the identification of Aristoxenus as the source of this section in Iamblichus see Staab 2002, p. 404.

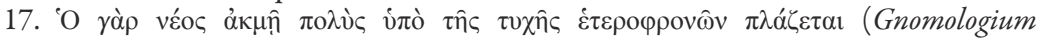
Vaticanum, 17).

18. Numenius, fr. 24, 34-36 (Des Places 1973).

19. In Diogenes Laertius, Lives of the Philosophers, X, 11 . 


\section{II}

It is fairly often asserted of Epicurus, both by himself and by others, that he cultivated a life comparable to the gods, a life comparable to that of Zeus in its felicity. ${ }^{20}$ Indeed we remember Lucretius' exclamation: 'deus ille fuit, deus' (De rerum natura, V, 8). Both Epicurus and his closest followers and family, for example Metrodorus, shared in this life, and the divine life they enjoyed together can be regarded as an imitation of the happy life thought to be shared by the gods. ${ }^{21}$ However, the figure of Epicurus himself assumed such importance in the Epicurean tradition that the Epicurean imitation of divine life was to become simply an 'imitatio Epicuri.22

Epicurus was regarded by his followers as a saviour of humanity. ${ }^{23}$ Through the knowledge he had brought to humans, he liberated them from misery, superstitions, ungrounded fears, unnecessary desires. As such he was indeed the great benefactor of humanity extolled in Lucretius' poem (De rerum natura, I, 62-79).

In his lifetime Epicurus instituted feast-days in his community, a practice faithfully observed in later Epicurean schools. ${ }^{24}$ These feasts were yearly in honour of himself, his parents, his brothers and closest disciples - and monthly (on the $20^{\text {th }}$ day) - in honour of himself and Metrodorus. It was, in fact, a hero cult..$^{25}$ The feasts were elaborate affairs, with meals and the reading of texts about those honoured. In describing these festivities, Plutarch, an unsympathetic critic of Epicureanism, asks:

What is the meaning of your common meals? And what of the gatherings of your associates and the fine people who join them? And what of the countless lines devoted to Metrodorus, Aristoboulos and Chairedemos, laboriously composed and collected to preserve their memory even in death? ${ }^{26}$

Elsewhere, Plutarch evokes a scene involving Epicurus himself:

20. Epicurus' Letter to Menoeceus (135); his letter to his mother preserved by Diogenes of Oinoanda, fr. 125 (Smith 1993); Us. 612; Gnomologium Vaticanum, 33.

21. See Baltes 2005, p. 111-135; Koch Piettre 2005.

22. Baltes 2005, p. 130.

23. For Epicurus as 'saviour', see Festugière $1968^{2}$, p. 63 n. 1 (citing Philodemus, Plotina and Lucian); Baltes 2005, p. 129 n. 132 (citing Philodemus and Diogenes of Oinoanda).

24. See Epicurus' testament in Diogenes Laertius, X, 18.

25. See Clay 1998, chapter 5, to whose work I am indebted in the following. For an earlier discussion see Boyancé 1937, p. 322-327; Festugière 1968², p. 31-33. Boyancé also discusses evidence of hero cult in Plato's Academy.

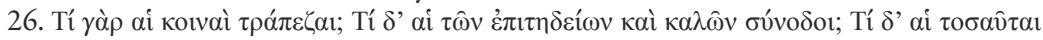

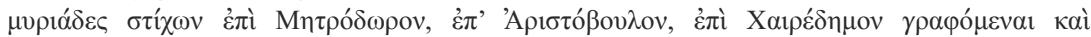

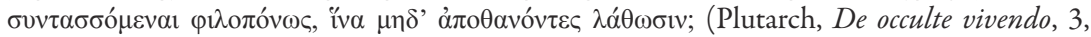
1129A; a hostile witness, Plutarch does not distinguish here between Epicurean yearly and monthly feasts). I quote Clay's translation, in the useful collection of pertinent texts he provides, 1998, p. 91-95. 
Even though he was suffering from a disease called 'askites' he would bring some of his friends together for a dinner and did not refrain from exacerbating his dropsy by taking liquid and melted with a peculiar kind of pleasure mixed with tears as he recalled the last words of Nicocles [his brother]. ${ }^{27}$

These feasts seem in this way to have involved and given rise to a considerable literary production, now almost entirely lost, in which the lives of the heroes thus honoured were recalled. We find traces of this literature, not only in the list of Epicurus' own writings (he wrote about the life of his brothers and closest disciples), but also in the lists of works by later Epicureans, Philodemus and others, who wrote about Epicurus' life and the life of other Epicurean heroes. ${ }^{28}$

What puzzled critics of Epicureanism such as Plutarch in all of this was the fact that dead heroes were celebrated, even though the Epicureans rejected the immortality of the soul: what sense can there be in celebrating that which had since been entirely dispersed? However, the criticism misses the point of such celebrations, which is succinctly put in the following fragment: 'The veneration of the wise man is a great good to him who venerates. ${ }^{29}$ Hearing the ideal, divine life led by a wise man such as Epicurus would inspire the follower, providing a model to emulate in his or her own life, to imitate as a way of living (and dying). Thus, for example,

The life of Epicurus, compared to that of others, might be thought to be a myth (muthos), because of its gentleness and self-sufficiency. ${ }^{30}$

The lives of Epicurus and of other Epicurean heroes, as works to be read and heard, thus had the mythical quality of an ideal of perfection which could benefit the reader and hearer by providing a model for emulation ${ }^{31}$ which would bring happiness.

Unfortunately, the Epicurean biographies of heroes, as exemplars of wise living, as we have seen, are now almost completely lost. But we can still read at least the encomiastic sections of Diogenes Laertius' last book (X, 9-12), where Epicurus' virtues are brought out: his gratefulness, beneficence, gent-

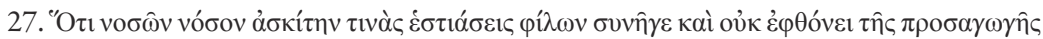

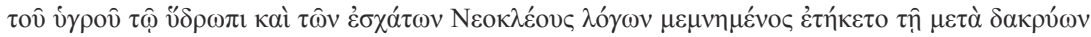

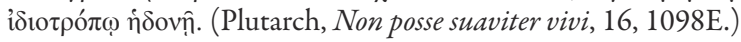

28. See the listing in Erler 1994, p. 50-51, with the corresponding sections for the individual authors. Epicurean biographical literature included not only edificatory encomia of Epicurean heroes such as those I describe here, but also historical, documentary, archival texts; on this distinction see most recently De Sanctis 2016. Hessler 2015 provides an interesting discussion of the origins of Epicurean commemoration of (Epicurean) heroes in the rhetorical genre of funeral speeches (which also called for imitation of the virtue of the dead).

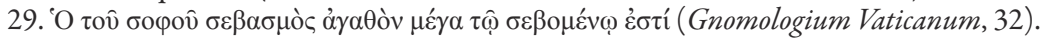

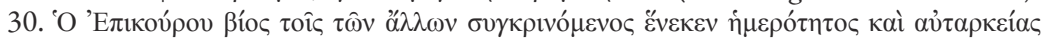

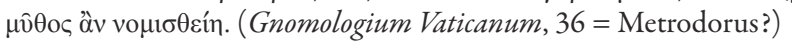

31. See Lucretius, DRN III, 3-6. 
leness, philanthropy, piety and friendliness.

Finally, one might note also that the story of Epicurus' divine existence, an ideal in words, would be accompanied by visual images of him - one is tempted to say icons -, in pictures, on bowls and on rings, which the Epicureans would keep in their bedrooms and carry around with them. ${ }^{32}$ These images could also inspire and remind disciples of the ideal of life which they sought to achieve. To these verbal and visual reminders of human perfection, the Epicurean would add the memorization of precepts, of 'principal doctrines', of sayings $s^{33}$ to be constantly recalled in the cultivation of a true Epicurean way of living.

\section{III}

There are some intriguing resemblances between Iamblichus' hero Pythagoras and Epicurus. Both were from Samos and left it. Both founded sects whose membership was fairly exclusive. The authority of the founder of each movement for its members was exceptionally great as compared to other ancient philosophical schools. We have seen in particular that both Epicurus and Iamblichus' Pythagoras are divine sages, ${ }^{34}$ benefactors of mankind, saviours of humanity through the knowledge which they brought, models to be imitated by their followers in the exemplary lives they led, their wisdom to be memorized, in the form of precepts and other texts, and constantly recalled. We have observed above (in section I) Epicurean traits in Iamblichus' portrayal of the Pythagorean life-style, as Pythagoras exemplified it in his own life and as he taught it to his disciples, a life characterized by stability and serenity of body and soul, a life of discipline of the desires and passions producing tranquillity and freedom from perturbation, a life shared with others, free from strife.

We can relate these Epicurean traits in Iamblichus' portrait of Pythagoras to a wider context, the use that had been made of biography in the Epicurean schools as a pedagogical tool (above section II). However, if we can see that the Epicurean use of biography provides in some respects a précédent to Iamblichus' account of Pythagoras as a philosophical hero and model, it would be difficult - and quite another thing - to show that Epicurean biographical texts could have constituted a direct or indirect source which inspired Iamblichus. The major difficulty for such an attempt to identify sources is the massive loss, not only of Epicurean biographical literature, but also of Academic, Peripatetic and Pythagorean/Platonist texts of a biographical

32. Cicero, Fin. V, 13; Pliny, HNXXXV, ii, 5.

33. Lucretius (DRN III, 12) speaks of 'aurea dicta', an expression which has been brought into relation with Pythagoras by Boyancé 1937, p. 322.

34. Of course divinity was conceived in Epicureanism and in late antique Platonism in very different ways. 
nature, some of which would also have provided sources of inspiration for Iamblichus. ${ }^{35}$ A further complication is presented by the inter-textual relationship Iamblichus' De vita Pythagorica seems to have with Porphyry's Vita Plotini. Both texts stand at the beginning of curricula, Porphyry's edition of Plotinus (the Enneads) which opens with the Vita Plotini, and Iamblichus' ten-volume synthesis of Pythagorean philosophy (On Pythagoreanism), of which the De vita Pythagorica is the first volume. It is not clear which reacts to which, Porphyry's life and edition of Plotinus responding to Iamblichus' programme to pythagoreanize Platonism, or the reverse. ${ }^{36}$ Porphyry's Plotinus is a 'philosopher of our times' (Vita Plotini, 1, 1), as compared with the mythical antiquity of Iamblichus' Pythagoras. Porphyry's Plotinus has features which contrast with Epicurean traits we have found in Iamblichus' Pythagoras. In particular Porphyry's Plotinus manifests, at the beginning of the Vita, an extreme neglect and rejection of the body not characteristic of Iamblichus' Pythagoras, who cultivates a well-regulated care of the body. In contrast to Epicurean practice, Porphyry's Plotinus does not tolerate the making of images of him (for Platonic reasons) and he refuses feasts in his name (although he does celebrate the birthdays of Plato and Socrates, Vita Plotini, 1, 4-9; 2, 39-40)

Notwithstanding these complexities and the loss of so much relevant source material, one need not go to the extreme of denying any possible relation between Iamblichus' De vita Pythagorica and Epicurean biography. Iamblichus composed the De vita Pythagorica probably near the end of the third century or early in the fourth century A. D. ${ }^{37}$ Already in the first century B. C., Philodemus had brought Epicureanism to the Roman élite. Lucretius and later Seneca, a Stoic, read Epicurus. Epicurean schools were still very much active well into the second century A. D., in Athens and in Asia Minor. ${ }^{38}$ A second century inscription names a certain Aurelius Belius Philippus, priest and 'head of the Epicureans in Apamea', ${ }^{39}$ a city associated with Numenius, ${ }^{40}$ with Plotinus' long-time pupil Amelius who retired there, the city where Iamblichus established his school. Again in the second century a certain Diogenes had inscribed on a great wall in Oinoanda, for all to read (citizens, foreign visitors and future generations), texts of Epicurus and

35. On the question of the variety of sources used in Iamblichus' De vita Pythagorica, see O'Meara 2014; on Iamblichus' use of Aristotle, see most recently De Cesaris 2018. Iamblichus referred to Epicurus in his (lost) commentary on Aristotle's Categories, but his information in this case may possibly have been mediated by Alexander of Aphrodisias (see O'Meara 2000, p. 245-246)

36. On this question see O’Meara 2014, p. 403-404.

37. See O'Meara 2014, p. 403-404

38. See Dorandi 2016, p. 35-36.

39. See Dorandi 2016, p. 36.

40. See above at n. 18 . 
documents showing the activities of Epicurean circles in Asia Minor at that time. In the same period, the Aristotelian professor in Athens, Alexander of Aphrodisias, engaged in polemics with Epicurean theories and, in the third century, Diogenes Laertius presented Epicurus and Epicurean documents in the last book of his Lives of the Philosophers, adding at the end (X, 139-149), as a 'colophon' to his book, Epicurus' Principal Doctrines. Active Epicurean schools were thus not far removed in time and place from Plotinus' school in Rome and from Iamblichus' school in Apamea and Epicurean literature and ideas were widely disseminated well into the third century. ${ }^{41}$

We should not therefore underestimate the extent to which Platonist philosophers in the third century were informed about Epicureanism and in certain respects even influenced by it, whatever might have been their sources of information, direct or indirect. Although major doctrinal differences (see above at n. 2) separated late antique Platonism from Epicureanism, Epicurean ideas, in particular in the domain of ethics, were adopted by late antique Platonists. Thus Plotinus and later Platonists made use, for example, of the Epicurean concept of katastematic pleasure ${ }^{42}$. More generally, Epicurean ethical precepts could be adopted on the level of an initial moral education. This is what is suggested by the extensive use made of Epicurean precepts, combined with other materials (including sayings attributed to Pythagoras in late antique anthologies ${ }^{43}$ ), in the elementary ethical instruction provided by Porphyry in his Letter to Marcella. ${ }^{44}$ Here, the precepts (Epicurus is not named) derive from Epicurus' letters, Principal doctrines and other Epicurean sources, as confirmed by citations in Cicero, Seneca and others. ${ }^{45}$ As an example one might quote a section from chapter 31 :

For the love of true philosophy causes every disturbing and painful desire to subside. Empty is the discourse of that philosopher by which no human passion is healed. For just as there is no benefit from medicine if it does not heal the bodies' diseases, neither is there from philosophy if it does not purge the passion of the soul. ${ }^{46}$

We have already observed above ${ }^{47}$ that Porphyry used Epicurean materials elsewhere, in the De abstinentia.

A comparable use of Epicurean ethical ideas has been found above (in

41. See Koch Piettre 2005, p. 41-51; Longo \& Taormina 2016, p. 2-3 and Dorandi 2016.

42. See O'Meara 1999 and 2000; the presence of Epicurean ethical ideas in Plotinus is unfortunately not fully examined in Longo \& Taormina 2016.

43. Stobaeus, Anthology, III, 1, 30-44. See Chadwick 1959, p. 143-148 and Des Places 1982, p. 95.

44. See Porphyry, Marc. 18 and 26-32.

45. See Porphyry, Marc. 27-31 with Des Places' apparatus and the notes in O'Brien Wicker 1987.

46. Transl. O'Brien Wicker 1987, who refers to Us. 457 and 221.

47. At note 15. 
section I) in Iamblichus' De vita Pythagorica. The portrayal of Pythagoras in De vita Pythagorica appears at the beginning of the Pythagorean curriculum assembled by Iamblichus in ten-volume treatise On Pythagoreanism. Thus the De vita Pythagorica corresponds, in the philosophical education of the soul, to the first steps in this education, the steps represented by 'ethical' and 'political' virtues, i.e. the first degrees in the hierarchy of virtues as conceived in late antique Platonism. ${ }^{48}$ Higher degrees in the hierarchy of virtues, in particular the 'theoretical' virtues, would be attained as the reader moved on further in the curriculum, to the later books of On Pythagoreanism.

These texts of Porphyry and Iamblichus show that Epicurean philosophy, notwithstanding numerous points of disagreement, could enter late antique Platonic philosophy, in particular at the initial stage of philosophical education, on the level of practical ethics, in the discipline of the body and of bodily desires. Of course another Hellenistic school, Stoicism, would have an even great impact on later Platonist ethics. ${ }^{49}$ Ideas derived from both schools, together with Aristotelianism, were assimilated, thanks to later Platonism's powerful capacity to integrate other philosophical currents.

Finally, we may have found a way of throwing some light on a minor puzzle. The Epicurean saying 'Live unnoticed!' (lathe biosas) was still known to be Epicurean by Themistius and the emperor Julian. ${ }^{50}$ However, in Marinus' Vita Procli, ${ }^{51}$ it is identified as being 'Pythagorean'. How could this identification have occurred? The saying is quoted by Marinus in a section (chapter 15) in which he is showing how Proclus, in his life, exemplified the 'political' virtues. The integration, or penetration, of Epicurean ethical ideas and Epicurean precepts which we have found in Porphyry and Iamblichus, on the level of lower degrees of the education of the soul, would have made the slippage here of an Epicurean saying into Pythagorean clothing relatively easy. ${ }^{52}$

48. See Staab 2002, p. 463-471.

49. A point noted by G. Boys-Stones in discussion.

50. Us. 551; see Roskam 2007, p. 44 and 69.

51. Marinus Procl. 15, 31 ed. Saffrey \& Segonds 2001.

52. It is possible that Apollonius of Tyana, who regarded himself as Pythagorean and made the Epicurean saying (not identified as Epicurean) into a favourite slogan (see Roskam 2007, p. 152), might have contributed to the slippage. 


\section{BIBLIOGRAPHY}

Baltes, M. 2005 : « Nachfolge Epikurs. Imitatio Epicuri », in M. Baltes, Epinoemata. Kleine Schriften zur antiken Philosophie und homerischen Dichtung, Hrsg. von M.-L. Lakmann, München, 2005 (Beiträge zur Altertumskunde, 221), p. 111-135.

Bonazzi, M. \& S. Schorn 2016 (éd.) : Bios philosophos. Philosophy in Ancient Greek Biography, Turnhout, 2016 (Philosophie hellénistique et romaine, 4).

Bouffartigue, J. \& M. Patillon 1977 (éd.) : Porphyre, De l'abstinence, 3 vol., Paris, 1977 (Collection des Universités de France. Série grecque).

BoyancÉ, P. 1937 : Le Culte des Muses chez les philosophes grecs : études d'histoire et de psychologie religieuse, Paris, 1937.

Chadwick, H. 1959 (éd.) : The Sentences of Sextus : a Contribution to the History of Early Christian Ethics, Cambridge, 1959.

Clark, G. 1989 (trad.) : Iamblichus, On the Pythagorean Life, Liverpool, 1989 (Translated Texts for Historians. Greek Series).

Clay, D. 1998 : Paradosis and Survival: three Chapters in the History of Epicurean Philosophy, Ann Arbor, 1998.

De Cesaris, G. 2018 : « Iamblichus' Investiture of Pythagoras », Methexis, 30 (2018), p. 175-196.

DOI : https://doi.org/10.1163/24680974-03001010

De SAnCtis, D. 2016 : « La biografia del Kñ $\pi$ oৎ e il profilo esemplare del saggio epicureo », dans BonazzI, M. \& S. SCHORn 2016 (éd.), p. 71-99.

Des Places, É. 1973 (éd.) : Numénius, Fragments, Paris, 1973 (Collection des Universités de France. Série grecque).

Des Places, É. 1982 (éd.) : Porphyre, Vie de Pythagore; Lettre à Marcella, avec un appendice d'A.-P. Segonds, Paris, 1982 (Collection des Universités de France. Série grecque).

Deubner, L. 1975 (éd.) : Iamblichus, De vita Pythagorica, editionem addendis et corrigendis adjunctis curavit U. Klein, Stuttgart, 1975 (Bibliotheca scriptorum graecorum et romanorum Teubneriana).

DORANDI, T. 2016: « The school and texts of Epicurus in the early centuries of the Roman empire », dans Longo, A. \& D. TAORmina 2016 (éd.), p. 29-48.

ERLER, M. 1994 : «Epikur »; « Die Schule Epikurs », dans M. Erler, H. Flashar et al. (éd.), Die Philosophie der Antike, vol. 4, Die Hellenistische Philosophie, Basel, 1994, p. 33-380.

Festugière, A.-J. $1968^{2}$ : Épicure et ses dieux, Paris, $1968^{2}$ (Mythes et religions, 19).

Gigante, M. \& W. Schmid 1977 (éd.) : Hermannus Usener, Glossarium Epicureum, Roma, 1977 (Lessico intellettuale europeo, 14).

Goulet, R. 2001 : « Les Vies de philosophes de l'Antiquité tardive », dans R. Goulet, Études sur les vies de philosophes de l'Antiquité tardive: Diogène Laërce, Porphyre de Tyr, Eunape de Sardes, Paris, 2001 (Textes et Traditions, 1), p. 3-63.

Hartmann, U. 2018 : Der spätantike Philosoph. Die Lebenswelten der paganen Gelehrten und ihre hagiographische Ausgestaltung in den Philosophenviten von Porphyrios bis Damaskios, 3 Bd., Bonn, 2018 (Antiquitas. Reihe 1, Abhandlungen zur alten Geschichte, 72). 
Hessler, J. E. 2015 : «Das Gedenken an Verstorbene in der Schule Epikurs in der Tradition der غ̇ंıน́́ tioni epicuree, Sankt Augustin, 2015, p. 95-112.

Koch Piettre, R. 2005 : Comment peut-on être dieu ? La secte d'Épicure, Paris, 2005 (L'Antiquité au présent).

Longo, A. \& D. Taormina 2016 (éd.) : Plotinus and Epicurus : Matter, Perception, Pleasure, Cambridge, 2016.

MaCris, C. 2006 : « Becoming divine by imitating Pythagoras ? », Mètis, 4 (2006), p. 297-329.

DOI : $10.4000 /$ books.editionsehess.3429

O’Brien Wicker, K. 1987 (éd.) : Porphyry the Philosopher, To Marcella, text and transl. with introduction and notes, index verborum by L. E. Klosinski, Atlanta, 1987 (Texts and Translations, Society of Biblical Literature. Graeco-Roman Religion Series, 10).

O’Meara, D. 1999 : « Epicurus Neoplatonicus », dans T. Fuhrer \& M. Erler (éd.), Zur Rezeption der hellenistischen Philosophie in der Spätantike: Akten der 1. Tagung der Karl-und-Gertrud-Abel-Stiftung vom 22. - 25. September 1997 in Trier, Stuttgart, 1999 (Philosophie der Antike, 9), p. 83-91.

O’Meara, D. 2000 : « Epikur bei Simplikios », dans M. Erler (éd.), Epikureismus in der späten Republik und der Kaiserzeit : Akten der 2. Tagung der Karl-undGertrud-Abel-Stiftung vom 30. September - 3. Oktober 1998 in Würzburg, hrsg. von M. E. in Zusammenarbeit mit R. Bees, Stuttgart, 2000 (Philosophie der Antike, 11), p. 243-251.

O'Meara, D. 2014 : « Iamblichus' On the Pythagorean Life in Context », dans C. A. Huffman (éd.), A History of Pythagoreanism, Cambridge, 2014, p. 399-415.

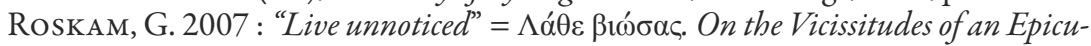
rean Doctrine, Leiden/Boston, 2007 (Philosophia antiqua, 111).

Saffrey, H. D. \& A. Segonds 2001 (éd.) : Marinus, Proclus ou Sur le bonheur, Paris, 2001 (Collection des Universités de France. Série grecque).

Sмith, M. F. 1993 (éd.) : Diogenes of Oinoanda, The Epicurean inscription, Naples, 1993 (La scuola di Epicuro. Supplemento, 1).

StaAв, G. 2002 : Pythagoras in der Spätantike. Studien zu De vita Pythagorica des Iamblichos von Chalkis, München, 2002 (Beiträge zur Altertumskunde, 165).

Urbano, A. P. 2013 : The Philosophical Life. Biography and the Crafting of Intellectual Identity in Late Antiquity, Washington D.C., 2013 (Patristic Monograph Series, 21).

Usener, H. 1887 (éd.) : Epicurea, Leipzig, 1887. 